\title{
PENDAKIAN DI JAWA TENGAH: MOTIVASI EKOWISATA DAN PERILAKU WISATAWAN
}

\author{
Fadlilaili Whahda Sabila ${ }^{1}$, Evi Yulia Purwanti ${ }^{2}$ \\ Universitas Diponegoro \\ fadlilailiws@gmail.com
}

\begin{abstract}
High interest in hiking is influenced by tourist behavior, so that it will potentially increase negative impact due to tourist activities in vulnerable areas. Tourist behavior in decision making can be estimated through the demand side of hiking. This research aims to analyze the factors that influence number of individual visits to the hiking sites in Central Java. The result showed seven variables influence the number of individual visits to hiking sites, those are physical motivation, landscape value, natural value, tourist facilities, accessibility, travel cost, and other tourism site. In the development of mountain-based tourism should pay attention to the alignment of tourism aspects and ecotourism principles.
\end{abstract}

Keywords: Hiking, ecotourism, tourist behavior, site attractions, site attributes.

JEL Classification: D91, Q21, Q26

\section{PENDAHULUAN}

Aspek pelestarian pada kawasan wisata alam menajadi hal yang penting untuk menjaga kualitas destinasi wisata alam. Kepariwisataan alam kemudian bergeser ke arah wisata minat khusus (special interest tourism). Wisata minat khusus merupakan jenis wisata yang memiliki unsur petualangan dan dilakukan oleh kelompok - kelompok kecil (individual tourism), serta dilakukan di alam bebas (Fandeli dan Nurdin, 2005). Wisata minat khusus kemudian dikembangkan lagi ke arah ekowisata. Ekowisata merupakan jenis wisata yang menekankan pada kegiatan konservasi dan idealnya dilakukan di kawasan yang dilindungi. Pergeseran kedua pola pariwisata tersebut menyebabkan wisata alam menjadi sangat berperan untuk menjaga kelestarian ODTW. Kedua pola pariwisata ini dapat dilakukan pada obyek wisata pendakian, dimana pada obyek wisata ini memiliki unsur - unsur wisata minat khusus dan dilakukan di kawasan yang rentan terhadap kerusakan lingkungan.

Wisata pendakian di Jawa Tengah telah lama digemari dan sudah menjadi tren di kalangan wisatawan lokal maupun internasional. Perubahan gaya hidup dan perilaku konsumen akan terus mendorong minat wisatawan untuk mendaki gunung. Konsumen akan memilih opsi yang paling populer dalam membuat keputusan, hal tersebut kemudian akan mendorong efek ikut - ikutan (Herpen, Pieters, dan Zeelenberg, 2009). Peningkatan preferensi terhadap minat mendaki gunung banyak menimbulkan argumen terhadap dampak negatif yang ditimbulkan dari aktivitas 
wisatawan, seperti sampah bekas pendaki, perusakan vegetasi, pengambilan tanaman langka, erosi tanah, dan perusakan habitat margasatwa (Santarém et al., 2015). Canteiro (2018) menjelaskan beberapa dampak negatif dari kegiatan wisata di kawasan pendakian yaitu, peningkatan permintaan terhadap pemanfaatan sumber daya alam dan peningkatan volum sampah yang dihasilkan. Dampak negatif yang ditimbulkan perlu segera dikelola untuk menjamin nilai - nilai pelestarian alam, khususnya kawasan wisata pendakian. Kecenderungan pertumbuhan ini perlu mendapat perhatian dari pengelola kawasan tersebut terutama pada kawasan terlindungi yang rentan akan kerusakan (Santarém et al., 2015).

Hasil pra survey dua puluh responden menunjukan sejumlah $60 \%$ pendaki tertarik untuk melakukan kegiatan konservasi selama kegiatan pendakian berlangsung. Namun, masih terdapat $40 \%$ pendaki belum mengetahui tentang kegiatan konservasi, belum pernah melakukan kegiatan konservasi, serta belum menyadari pentingnya pelestarian lingkungan saat mendaki gunung. Sehingga, semakin banyak wisatawan yang berkunjung berpotensi meningkatkan kerusakan lingkungan pada kawasan pendakian di Jawa Tengah.

Tingginya minat wisata pendakian di Jawa Tengah menjadi sangat berpotensi untuk dikembangkan. Namun, kegiatan ekonomi baik konsumsi atau produksi dapat menimbulkan pencemaran, dengan demikian, pengembangan wisata pendakian menjadi sebuah dilema. Daya tarik wisata pendakian sangat bergantung pada tingkat kelestarian alam. Sehingga, pengembangan wisata ini harus selaras dengan upaya pelestarian yang dilakukan oleh pihak pengelola maupun pengunjung yang dapat berinteraksi langsung dengan alam. Analisis terhadap perilaku individu yang dapat mencemari lingkungan menjadi perlu untuk dilakukan (Sukanto, 2000). Perilaku individu dalam memutuskan tempat tujuan wisata dapat dilihat melalui aspek permintaan terhadap motivasi untuk mendaki gunung. Oleh karena itu, perlu mengetahui faktor - faktor yang memengaruhi tingkat kunjungan wisata pendakian di Jawa Tengah terhadap kepuasan sekaligus motivasi wisatawan untuk melakukan upaya pelestarian lingkungan.

\section{TINJAUAN PUSTAKA}

\section{Teori Permintaan}

Teori permintaan menjelaskan tentang hubungan antara jumlah permintaan dengan berbagai tingkat harga yang tersedia. Hubungan antara jumlah barang yang diminta pada berbagai tingkat harga digambarkan melalui kurva permintaan. Kurva permintaan memiliki kemiringan yang menurun ke bawah. Hal tersebut menunjukan hubungan negatif antara jumlah barang yang diminta dengan tingkat harga pasar. Faktor - faktor yang dapat memengaruhi permintaan dituliskan dalam fungsi permintaan sebagai berikut:

$$
D x=f(P x, P y, M, S)
$$

Berdasarkan Persamaan 1, faktor - faktor yang dapat memengaruhi permintaan (Dx) yaitu : harga barang itu sendiri (Px), harga barang lain (Py), pendapatan (M), dan selera (S) (Case dan Fair, 2007).

Dalam beberapa jenis barang, permintaan individu dapat dipengaruhi oleh permintaan individu lain dan kemudian disebut sebagai eksternalitas jaringan. 
Eksternalitas jaringan dapat bersifat positif dan negatif (Pindyck dan Rubinfeld, 2005). Salah satunya terdapat pada beberapa jenis pariwisata. Beberapa pola permintaan pariwisata merupakan hasil keputusan irasional (Sinclair dan Stabler, 1997). Perilaku irasional konsumen dapat dijelaskan melalui efek ikut - ikutan (bandwagon effect) yang merupakan jenis eksternalitas jaringan positif, efek snob (snob effect) jenis eksternalitas jaringan negatif, dan efek pamer (conspicuous consumption/Veblen effect) (Sudarsono, 1983).

\section{Pariwisata dan Permintaan Pariwisata}

Pariwisata adalah perjalanan dari satu tempat ke tempat lain yang bersifat sementara sebagai usaha mencari keseimbangan dengan lingkungan hidup dalam dimensi sosial, budaya, alam, dan ilmu pengetahuan (Spillane, 1987). Mengacu pada definisi tersebut, sektor pariwisata merupakan sektor multidimensi yang memiliki pengaruh atas keterkaitan sektor lain dalam kegiatan kepariwisataan.

Faktor utama penentu permintaan pariwisata adalah preferensi dan anggaran. Anggaran pengeluaran yang dikeluarkan tergantung pada jumlah jam kerja yang dicurahkan. Jumlah jam kerja akan memengaruhi tingkat pendapatan dan kemudian akan memengaruhi alokasi anggaran pengeluaran individu (Sinclair dan Stabler, 1997). Selain ditentukan oleh anggaran yang siap dibelanjakan, permintaan pariwisata juga ditentukan oleh preferensi konsumen terhadap konsumsi barang dan jasa lain. Konsumen akan mempertimbangkan anggarannya, apakah digunakan untuk berwisata atau untuk mengonsumsi barang dan jasa lain. Konsumen akan memilih titik yang paling optimal untuk memaksimalkan kepuasannya sesuai pada jumlah anggaran belanja (Sinclair dan Stabler, 1997). Kombinasi antara berwisata dengan konsumsi barang dan jasa lain diilustrasikan oleh Gambar 1 berikut:

\section{Gambar 1}

\section{Preferensi Individu Terhadap Pariwisata dan Barang Lain}

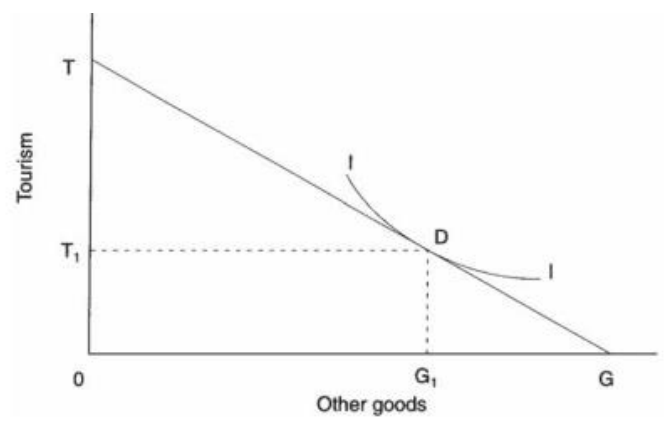

Sumber : Sinclair dan Stabler, 1997

Titik D pada Gambar 1 merupakan titik yang paling optimum dari kombinasi tersebut. Titik D dapat dituliskan sebagai fungsi permintaan pariwisata yaitu sebagai berikut :

$D=f\left(X_{1}, X_{2}, \ldots X_{n}\right)$

D merupakan permintaan pariwisata, sedangkan $X_{1}, X_{2}, X_{n}$ merupakan variabel independen yang dapat memengaruhi permintaan pariwisata. Variabel independen tersebut dapat berupa faktor - faktor non ekonomi, seperti faktor sosial 
dan psikologis. Selain itu, permintaan pariwisata dapat ditentukan oleh kombinasi berwisata dengan jenis wisata lain. Hal tersebut dapat menunjukan hubungan antara dua kombinasi tipe pariwisata yang berbeda, apakah bersifat substitusi atau komplementer (Sinclair dan Stabler, 1997).

\section{Ekowisata}

Ekowisata merupakan jenis wisata yang berbeda dengan jenis wisata konvensional pada umumnya. Ekowisata merupakan kegiatan wisata yang menekankan pada kelestarian sumber daya pariwisata. Ekowisata dapat diartikan sebagai perjalanan wisata alam yang bertanggungjawab dengan cara melakukan kegiatan konservasi sebagai akibat dari aktivitas wisatawan (The International Ecotourism Society, dalam Damanik dan Weber, 2006).

Konsep yang mendasari adanya ekowisata yaitu perjalanan di kawasan alam yang tidak menimbulkan kerusakan lingkungan. Sementara itu, prinsip - prinsip dalam ekowisata yaitu : mengurangi dampak negatif dari aktivitas wisatawan, membangun kesadaran lingkungan, serta memberikan keuntungan finansial secara langsung bagi keperluan konservasi melalui pengeluaran wisatawan (Damanik dan Weber, 2006). Wisatawan tidak hanya dituntut untuk memiliki kesadaran lingkungan, tetapi juga mampu melakukannya melalui kegiatan wisata dalam bentuk ketersediaan membayar untuk pemeliharaan lingkungan.

\section{Pendekatan Hedonic Pricing}

Teknik hedonic pricing pada prinsipnya adalah mengestimasi nilai implisit atribut yang melekat pada suatu barang dan jasa, serta mengkaji hubungan antara nilai implisit tersebut dengan permintaan barang dan jasa (Fauzi, 2004). Pendekatan ini digunakan untuk memastikan nilai kesenangan dari suatu atribut. Harga implisit (harga hedonis) dari nilai atribut tersebut tidak tersedia sebagai harga pasar (non market value). Model harga hedonis telah banyak diterapkan dalam industri pariwisata untuk menentukan faktor - faktor yang dapat memengaruhi motivasi dan tujuan wisata. Fungsi utama dari pendekatan harga hedonis adalah untuk mengidentifikasi faktor - faktor harga berdasarkan pada premis bahwa harga ditentukan oleh karakteristik yang melekat pada barang dan jasa.

Perluasan dari hedonic pricing yaitu hedonic travel cost method yang dikembangkan oleh Yen dan Sohngen (2004), dimana untuk memperoleh harga implisit dari atribut obyek wisata adalah dengan mergresi biaya perjalanan yang dikeluarkan terkait dengan atribut wisata. Dengan demikian, perilaku pengunjung untuk memaksimalkan utilitasnya adalah sama dengan jumlah anggaran yang siap dibelanjakan. Kondisi equilibrium wisatawan akan terjadi ketika utilitas marjinal atribut wisata sama dengan biaya marjinal dan ketersediaan membayar marjinalnya (marginal willingness to pay) dari tiap atribut yang dirasakan.

\section{Penelitian Terdahulu}

1. Frederico Santarem, Rubim Silva, Paulo Santos (2015); Assesing Ecotourism Potential of Hiking Trails : A Framework to Incorporate Ecological and Cultural Features and Seasonality

Frederico Santarem, Rubim Silva, Paulo Santos (2015) dalam penelitiannya menganalisis nilai potensial ekowisata pada jalur pendakian. 
Penelitian tersebut menggunakan variabel - variabel fitur ekologi dan budaya lokal. Penilaian potensi ekowisata pada jalur pendakian meliputi spesies, habitat alami, sumber daya alam dan budaya lokal, serta memasukan unsur perbedaan musim.

2. Ping Li, Zhou Bin, Chris Ryan (2017) ; Hiking in China : A Fuzzy Model of Satisfaction

Ping Li, Zhou Bin, Chris Ryan (2017) membuat indeks evaluasi kepuasan dari wisata pendakian di Cina. Penelitian ini menggunakan permodelan fuzzy untuk mengidentifikasi nilai atribut yang dapat memengaruhi kepuasan pendaki gunung di Cina. Berdasarkan leisure satisfaction scale, tingkat kepuasan dalam mendaki gunung dapat dilihat melalui aspek psikologis, edukasi, sosial, relaksasi, fisik, dan aestetik.

3. Abdurahman, Jati Kusuma Ali, Khedif, Bokhari, Ahmad, Kibat (2016) ; Ecotourism Product Attributes and Tourist Attractions:UiTM Undergraduate Studies

Abdurahman, Jati Kusuma Ali, Khedif, Bokhari, Ahmad, Kibat (2016) melakukan analisis terhadap minat wisatawan untuk berkunjung ke obyek ekowisata di Sarawak, Malaysia. Analisis faktor digunakan untuk menentukan atribut ekowisata. Selanjutnya, analisis linear berganda digunakan untuk melihat atribut yang paling memengaruhi minat berekowisata yaitu atribut budaya, alam, daya tarik, dan komunitas.

4. Aditya Emka Nugraha, Evi Yulia Purwanti (2015) ; Analisis Faktor-Faktor yang Mempengaruhi Permintaan Pengunjung Obyek Wisata Menara Kudus Melalui Pendekatan Hedonic Pricing Method

Aditya Emka Nugraha dan Evi Yulia Purwanti (2015) mengestimasi model permintaan pada obyek wisata Menara Kudus dengan pendekatan hedonic pricing serta menganalisis faktor - faktor yang dapat memengaruhi tingkat kunjungan wisata Menara Kudus. Regresi logistik multinomial digunakan untuk mengestimasi permintaan obyek wisata Menara Kudus melalui probabilitas tingkat kunjungan wisata dalam satu tahun. Hasilnya menunjukan bahwa pendapatan dan nilai implisit atribut wisata berpengaruh terhadap keputusan wisatawan untuk berkunjung ke obyek wisata Menara Kudus.

5. Chia-Yu Yeh and Brent L. Sohngen, (2004); Estimating Dynamic Recreational Demand by the Hedonic Travel Cost Method

Chia-Yu Yeh and Brent L. Sohngen (2004) melakukan penelitian untuk menganalisis perubahan nilai - nilai pariwisata. Penelitian ini menghubungkan fungsi hedonic pricing dan biaya perjalanan dengan nilai atribut wisata. Penelitian ini juga menjelaskan perilaku pegunjung dalam memaksimalkan utilitasnya adalah sama dengan jumlah anggaran. Titik equilibrium wisatawan terjadi ketika utilitas marjinal atribut wisata sama dengan biaya marjinalnya yang bersedia dibayarkan (marginal willingness to pay) dari tiap atribut yang dirasakan. 


\section{METODE PENELITIAN}

\section{Populasi dan Sampel Penelitian}

Populasi dalam penelitian ini adalah pengunjung obyek wisata pendakian di Jawa Tengah yang tidak diketahui secara pasti setiap harinya. Sampel dalam penelitian ini menggunakan probability sampling dengan teknik proportionate stratified random sampling, yaitu sampel yang dihitung berdasarkan perbandingan jumlah populasi (Sugiyono, 2013). Responden dalam penelitian ini adalah wisatawan obyek wisata pendakian di Jawa Tengah yang direpresentasikan dengan empat obyek wisata pendakian, yaitu : Gunung Slamet, Gunung Merbabu, Gunung Prau, dan Gunung Andong (Pra Survey, 2019). Penelitian ini menggunakan penghitungan dengan menaksir parameter proporsi dengan $\alpha 5 \%$. Pengambilan sampel dilakukan dengan metode pengumpulan kuesioner. Berdasarkan penghitungan tersebut didapatkan jumlah sampel minimal yaitu 100 responden dengan proporsi sampel yang ditunjukan Tabel 1 sebagai berikut:

Tabel 1 Jumlah Sampel Penelitian

\begin{tabular}{clcc}
\hline No & \multicolumn{1}{c}{ Obyek Pendakian } & $\begin{array}{c}\text { Jumlah Pengunjung } \\
\text { tahun 2018 }\end{array}$ & $\begin{array}{c}\text { Jumlah } \\
\text { Sampel }\end{array}$ \\
\hline 1 & $\begin{array}{l}\text { Gunung Andong (Kabupaten } \\
\text { Magelang) }\end{array}$ & 28 \\
2 & $\begin{array}{l}\text { Gunung Prau (Kabupaten } \\
\text { Temanggung) }\end{array}$ & 13.000 & 8 \\
3 & $\begin{array}{l}\text { Gunung Merbabu (Kabupaten } \\
\text { Boyolali) }\end{array}$ & 79.000 & 46 \\
Gunung Slamet (Kabupaten & 30.000 & 18 \\
\hline & \multicolumn{1}{c}{ Total } & $\mathbf{1 7 0 . 0 0 0}$ & $\mathbf{1 0 0}$ \\
\hline \hline
\end{tabular}

Sumber: Data Primer 2019, diolah

\section{Metode Analisis Data}

Metode analisis data dalam penelitian ini menggunakan analisis regresi logistik multinomial karena variabel dependen dalam penelitian ini bersifat lebih dari dua kategorik (M kategori). Dalam regresi logistik multinomial, terdapat satu variabel dependen yang dijadikan sebagai kategori referensi. Berdasarkan data primer (2019), terdapat beberapa kemungkinan kekerapan individu mendaki gunung di Jawa Tengah, yaitu 1 - 10 kali berkunjung per individu dalam satu tahun terakhir (2018 - 2019). Kategori referensi dalam penelitian ini adalah tingkat kunjungan satu kali yang diberi kode 1, sedangkan kategori relatif yaitu tingkat kunjungan $2-10$ kali kunjungan yang kemudian diberi kode $2-10$. Rumusan model yang digunakan dalam penelitian ini adalah :

$$
\begin{aligned}
& \operatorname{Ln}=\frac{P(Y i=2,3,4,5,6,7,8,10)}{P(Y i=1)}=\alpha+\beta_{1} X_{1}+\beta_{2} X_{2}+\beta_{3} X_{3}+\beta_{4} X_{4} \beta_{5} X_{5}+\beta_{6} X_{6}+\beta_{7} X_{7}+\beta_{8} X_{8} \\
& +\beta_{9} X_{9}-\beta_{10} X_{10}+\beta_{11} X_{11}+e i
\end{aligned}
$$


$\operatorname{Ln}=\frac{P(Y i=2,3,4,5,6,7,8,10)}{P(Y i=1)} \quad:$ tingkat kunjugan wisata pendakian di Jawa Tengah

$\mathrm{X} 1 \quad$ : Keinginan konservasi

X2 : Pengetahuan konservasi

X3 : Kebutuhan relaksasi

X4 : Motivasi fisik

X5 : Nilai keindahan

X6 : Nilai keaslian/kelestarian
X7 : Atraksi obyek wisata

$\mathrm{X} 8$ : Sarana yang tersedia

X9 : Aksesibilitas obyek wisata

$\mathrm{X} 10$ : Biaya perjalanan

X11 : Obyek wisata lain

Sebelum melakukan analisis regresi logistik multinomial maka perlu dilakukan pengujian sebagai berikut (Ghozali, 2006) :

1. Menguji Kelayakan Model Regresi (Goodness of Fit)

Pengujian Goodness of Fit bertujuan untuk melihat apakah model mampu memprediksi hasil observasinya (Ghozali, 2006).

Dengan $\alpha 5 \%$, hipotesis yang digunakan untuk menilai kelayakan model adalah sebagai berikut :

$\mathrm{H}_{0}$ : model yang dihipotesiskan fit dengan data

$\mathrm{Ha}$ : model yang dihipotesiskan tidak fit dengan data

Jika probabilitas $>0,05$, maka $\mathrm{H}_{0}$ diterima. Artinya bahwa model dapat diterima karena cocok dengan data observasinya.

2. Menguji Keseluruhan Model (Overall Model Fit)

Overall model fit dilakukan untuk menguji apakah secara umum variabel independen memengaruhi variabel dependennya (Ghozali, 2006). Pengujian dilakukan dengan membandingkan nilai antara -2Loglikelihood (2LogL) pada awal dengan nilai -2LogL pada akhir. Adanya pengurangan nilai antara $-2 \log \mathrm{L}$ awal dengan -2LogL artinya bahwa model yang dihipotesiskan fit dengan data (Ghozali, 2006).

3. Menguji Koefisien Regresi (Likelihood Ratio Test)

Pengujian koefisien regresi bertujuan mengukur pengaruh variabel independen secara individual dapat menerangkan variasi variabel dependen (Ghozali, 2006). Dengan $\alpha 5 \%$, maka dasar pengambilan keputusan dalam penelitian ini, yaitu :

$$
\begin{aligned}
& \mathrm{P} \text { value } \mathrm{X}_{\mathrm{n}}>0,05 \text {, maka } \mathrm{H}_{0} \text { diterima } \\
& \mathrm{P} \text { value } \mathrm{X}_{\mathrm{n}}<0,05 \text {, maka } \mathrm{H}_{0} \text { ditolak }
\end{aligned}
$$

Dalam model regresi logistik, nilai dari masing - masing variabel independen $\mathrm{X}$ berkisar antara $-\infty$ sampai dengan $+\infty$. Sedangkan nilai Pi berada diantara 0 dan 1. Nilai Pi tidak berhubungan linear dengan $X$ dan $\beta$. Nilai $\beta i$ dari tiap variabel digunakan untuk melihat seberapa besar probabilitas variabel $\mathrm{Xi}\left(\mathrm{X}_{1}, \mathrm{X}_{2}, \mathrm{X}_{3}, \mathrm{X}_{4}, \mathrm{X}_{5}\right.$, $\left.\mathrm{X}_{6}, \mathrm{X}_{7}, \mathrm{X}_{8}, \mathrm{X}_{9}, \mathrm{X}_{10}, \mathrm{X}_{11}\right)$ berpengaruh terhadap variabel dependen yaitu tingkat kunjungan wisata pendakian di Jawa Tengah (Y). 


\section{Variabel Penelitian}

1. Tingkat Wisata Pendakian di Jawa Tengah (Y)

Jumlah kekerapan individu untuk mengunjungi obyek wisata pendakian di Jawa Tengah. Variabel ini diukur dalam satuan kekerapan (kali)/tahun.

2. Keinginan untuk Pelestarian $\left(\mathrm{X}_{1}\right)$

Dorongan untuk mendaki gunung dengan tujuan melakukan kegiatan konservasi.

3. Pengetahuan tentang Konservasi $\left(\mathrm{X}_{2}\right)$

Pengetahuan tentang konservasi merupakan tingkat pengetahuan tentang konservasi terhadap keputusan individu untuk melakukan wisata pendakian.

4. Kebutuhan Relaksasi $\left(\mathrm{X}_{3}\right)$

Kepuasan pengunjung dari manfaat relaksasi yang dirasakan secara langsung saat mendaki gunung.

5. Motivasi Fisik $\left(\mathrm{X}_{4}\right)$

Kepuasan pengunjung terhadap manfaat fisik yang dirasakan setelah mendaki gunung.

6. Nilai Keindahan $\left(\mathrm{X}_{5}\right)$

Nilai implisit dari karakteristik yang dimiliki obyek wisata pendakian gunung di Jawa Tengah.

7. Nilai Keaslian/Kelestarian $\left(\mathrm{X}_{6}\right)$

Nilai implisit yang berkaitan dengan tingkat kelestarian yang dimiliki obyek wisata pendakian gunung di Jawa Tengah.

8. Atraksi Obyek Wisata $\left(\mathrm{X}_{7}\right)$

Daya tarik alami ditawarkan obyek wisata pendakian gunung di Jawa Tengah, seperti padang sabana, air terjun, dan hutan pinus.

9. Sarana yang Tersedia $\left(\mathrm{X}_{8}\right)$

Kuantitas dan kualitas sarana yang tersedia dalam menunjang kegiatan serta sarana keamanan dan keselamatan pendaki.

10. Aksesibilitas Obyek wisata $\left(\mathrm{X}_{9}\right)$

Tingkat kemudahan menuju kawasan wisata pendakian, transportasi yang tersedia, serta kemudahan dan keamanan jalur menuju puncak.

11. Biaya Perjalanan Menuju Obyek Wisata $\left(\mathrm{X}_{10}\right)$

Biaya yang dikeluarkan untuk melakukan perjalanan menuju obyek wisata pendakian hingga kembali ke rumah yang meliputi biaya transportasi, konsumsi, dan registrasi.

12. Obyek Wisata Lain $\left(\mathrm{X}_{11}\right)$

Biaya yang dikeluarkan untuk melakukan perjalanan menuju obyek wisata Dataran Tinggi Dieng hingga kembali ke rumah yang meliputi biaya transportasi, konsumsi, dan registrasi.

\section{HASIL DAN PEMBAHASAN}

\section{Motivasi dan Preferensi Wisatawan}

Obyek penelitian dalam penelitian ini yaitu Gunung Slamet, Gunung Merbabu, Gunung Prau, dan Gunung Andong. Obyek wisata pendakian di Jawa Tengah yang direpresentasikan dengan keempat gunung - gunung tersebut memiliki 
fasilitas pendukung dan fasilitas keamanan pendakian yang telah terstandardisasi. Sehingga, keempat obyek tersebut memiliki kuantitas sarana yang hampir sama. Obyek wisata tersebut juga memiliki keanekaragaman flora dan fauna endemiknya masing - masing yang dapat menjadi daya tarik bagi para pendaki gunung. Hal tersebut menyebabkan motivasi untuk mendaki gunung menjadi sangat bervariasi.

\section{Gambar 2 Presentase Tujuan Mendaki Gunung di Jawa Tengah}

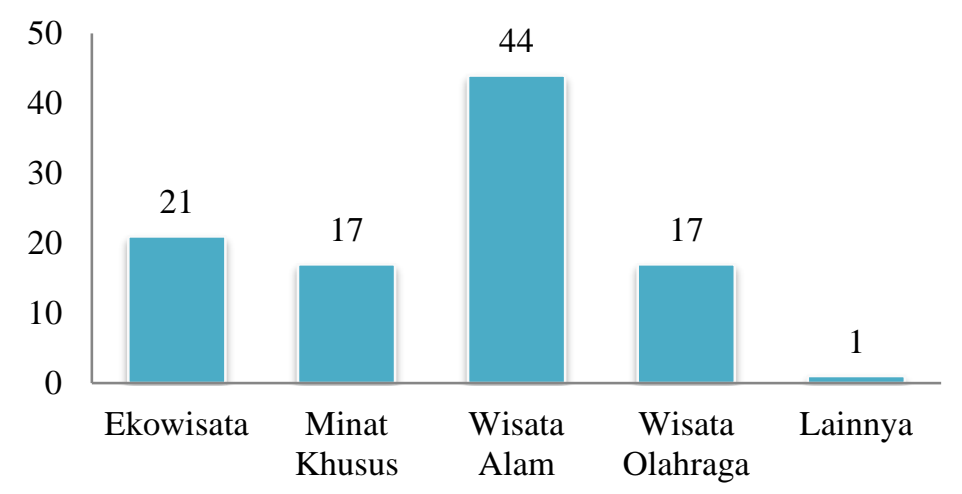

Sumber: Data Primer 2019, diolah

\section{Gambar 3 Presentase Aktivitas Wisatawan Saat Mendaki Gunung}

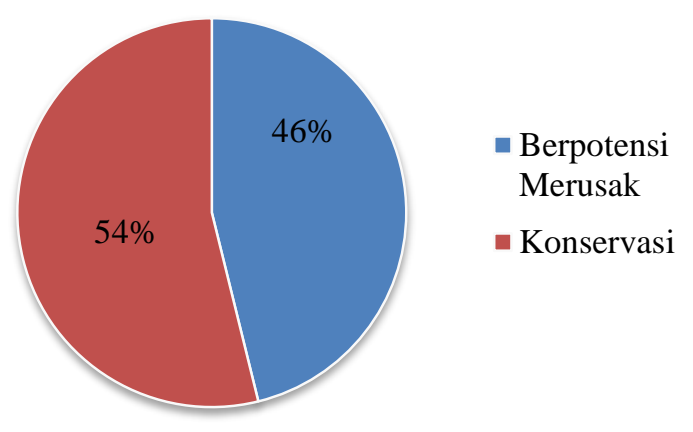

Sumber: Data Primer 2019, diolah

Berdasarkan Gambar 2, motivasi wisatawan untuk mendaki gunung di Jawa Tengah dapat diklasifikasikan berdasarkan preferensinya terhadap kegiatan ekowisata, kepuasan yang diperoleh dari mendaki gunung, daya tarik obyek, atribut wisata, dan karakteristik wisatawan itu sendiri. Selain itu, kegiatan wisatawan saat mendaki gunung dapat diklasifikasikan menjadi aktivitas yang berpotensi merusak lingkungan dan aktivitas konservasi, seperti yang dijelaskan Gambar 3.

Preferensi wisatawan merupakan nilai akumulasi indikator dari masing masing preferensi. Preferensi wisatawan terhadap motivasinya untuk mendaki gunung dapat diklasifikasikan menjadi : ketersediaan melakukan konservasi saat 
mendaki gunung, tingkat pengetahuan konservasi, manfaat relaksasi, manfaat fisik, daya tarik keindahan, daya tarik keaslian, daya tarik atraksi, sarana yang tesedia, aksesibilitas obyek wisata, dan kunjungan ke obyek wisata lain (Dataran Tinggi Dieng). Gambar 4 menunjukan nilai rata - rata akumulasi preferensi wisatawan. Semakin besar nilai skala, maka semakin tinggi preferensi wisatawan terhadap obyek wisata pendakian di Jawa Tengah.

\section{Gambar 4 Nilai Rata - Rata Akumulasi Preferensi Wisatawan}

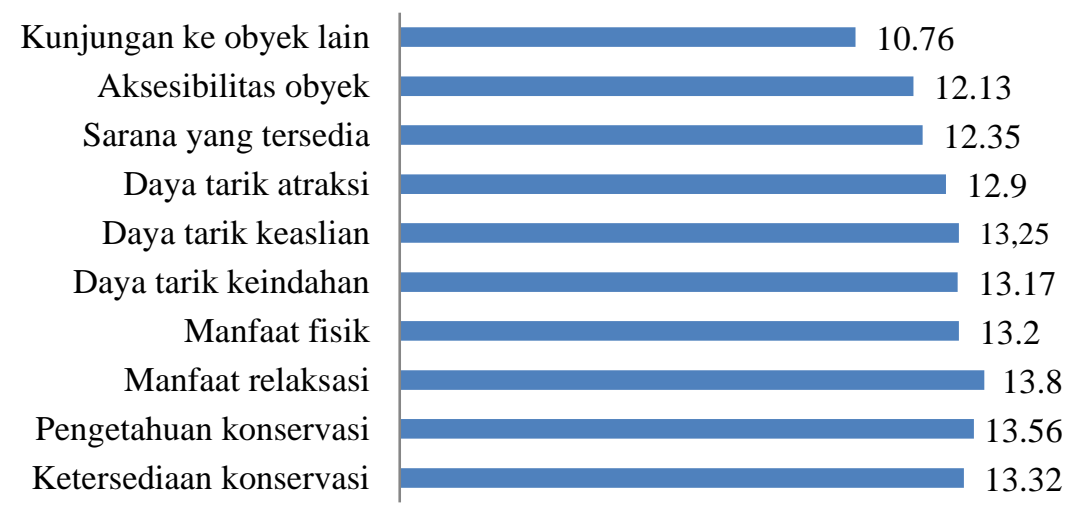

Sumber: Data Primer 2019, diolah

\section{Karakteristik Wisatawan}

Sampel yang diperoleh dalam penelitian ini sejumlah 100 wisatawan. Pengumpulan data dilakukan selama bulan Maret - April 2019 dan dilakukan pada hari kerja (Kamis - Jum'at) dan hari libur (Sabtu - Minggu). Responden dalam penelitian ini adalah para pendaki gunung yang berkunjung ke obyek wisata pendakian di Jawa Tengah. Obyek wisata pendakian di Jawa Tengah dalam penelitian ini di representasikan oleh Gunung Slamet, Gunung Merbabu, Gunung Prau, dan Gunung Andong. Tabel 2 berikut menjelaskan karakteristik sosial ekonomi wisatawan. 
Jurnal Dinamika Ekonomi Pembangunan

https://ejournal.undip.ac.id/index.php/dinamika_pembangunan/index

Tabel 2 Karakteristik Sosial Ekonomi Wisatawan

\begin{tabular}{|c|c|}
\hline \multirow{2}{*}{ Jenis Kelamin } & Laki - Laki (86\%) \\
\hline & Perempuan $(14 \%)$ \\
\hline Usia & $<24$ tahun $(70 \%)$ \\
\hline \multirow{3}{*}{ Pekerjaan } & Mahasiswa (57\%) \\
\hline & Swasta $(23 \%)$ \\
\hline & PNS $(7 \%)$ \\
\hline \multirow{2}{*}{ Daerah asal } & $\begin{array}{l}\text { Jawa Barat dan } \\
\text { Jabodetabek }(36 \%)\end{array}$ \\
\hline & $\begin{array}{l}\text { Jawa Tengah } \\
(64 \%)\end{array}$ \\
\hline \multirow{2}{*}{ Kendaraan } & $\begin{array}{l}\text { Kendaraan Umum } \\
(37 \%)\end{array}$ \\
\hline & $\begin{array}{l}\text { Motor Pribadi } \\
(56 \%)\end{array}$ \\
\hline \multirow{5}{*}{$\begin{array}{c}\text { Rerata biaya } \\
\text { perjalanan }\end{array}$} & $\leq 100.000(15 \%)$ \\
\hline & $\begin{array}{l}100.001-300.000 \\
(35 \%)\end{array}$ \\
\hline & $\begin{array}{l}300.001-500.000 \\
(33 \%)\end{array}$ \\
\hline & Min : 40.000 \\
\hline & Maks : 1.500 .000 \\
\hline Lama kunjungan & 2 hari $(74 \%)$ \\
\hline \multirow{2}{*}{$\begin{array}{c}\text { Status keanggotaan } \\
\text { pecinta alam/komunitas } \\
\text { lingkungan } \\
\end{array}$} & Anggota $(32 \%)$ \\
\hline & $\begin{array}{l}\text { Bukan anggota } \\
(68 \%)\end{array}$ \\
\hline
\end{tabular}

Sumber : Data Primer 2019, diolah

Berdasarkan Tabel 2 jumlah wisatawan yang melakukan wisata pendakian didominasi oleh laki-laki. Pada umumnya, laki - laki memiliki kondisi fisik yang kuat untuk mendaki gunung. Meskipun didominasi oleh laki-laki, wisata pendakian merupakan kebutuhan semua orang tanpa membedakan jenis kelamin. Karakteristik wisatawan didominasi oleh wisatawan yang berusia kurang dari 24 tahun. Dominasi tersebut disebabkan karena karakteristik wisata pendakian membutuhkan kekuatan dan gerak fisik, sehingga wisatawan dengan kategori usia muda cenderung lebih sering melakukan wisata pendakian. Jenis pekerjaan wisatawan mayoritas adalah pelajar/mahasiswa dengan jumlah 57 orang. Jenis pekerjaan pada umumnya mencerminkan waktu luang yang dimiliki seseorang untuk berwisata. Pelajar/mahaiswa masih memiliki banyak waktu luang, karena dalam mendaki gunung membutuhkan banyak waktu luang mulai dari persiapan hingga kegiatan berlangsung. 


\section{Gambar 5 Presentase Persebaran Daerah Asal Wisatawan}

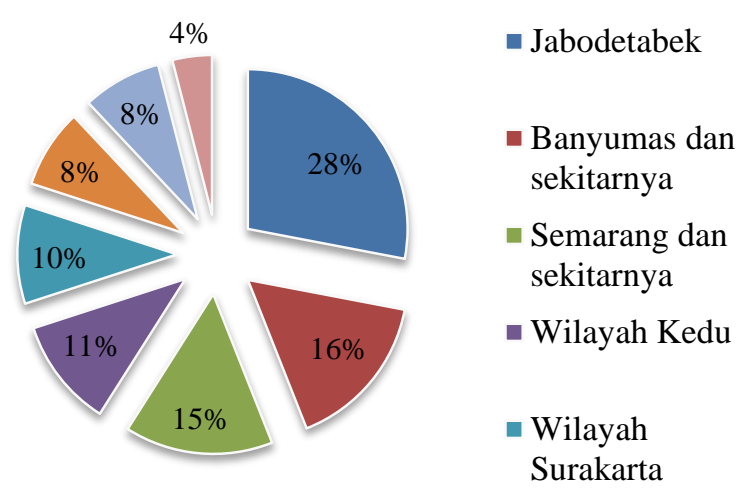

Sumber: Data Primer 2019, diolah

Mayoritas wisatawan menggunakan kendaraan sepeda motor pribadi. Hal tersebut juga menunjukan bahwa sebagian besar wisatawan yang mendaki gunung di Jawa Tengah tidak bersama rombongan besar. Rata-rata biaya perjalanan yang dikeluarkan berada pada kisaran biaya Rp 100.001 - Rp 300.000 dan Rp 300.001 $\mathrm{Rp}$ 500.000. Rerata biaya yang dikeluarkan untuk mendaki gunung di Jawa Tengah sangat bervariasi, hal tersebut dikarenakan obyek yang dikunjungi terletak pada lokasi yang berbeda. Berdasarkan Gambar 5, rincian persebaran daerah asal wisatawan mayoritas berasal dari wilayah Jabodetabek (Jakarta, Bogor, Depok, Tangerang, Bekasi) sebanyak 28\%. Gambar 5 menunjukan bahwa obyek wisata pendakian di Jawa Tengah juga diminati oleh pengunjung yang berasal dari daerah luar Jawa Tengah dan relatif jauh dari lokasi obyek wisata pendakian.

\section{Hasil Analisis Regresi Logistik Multinomial}

Hasil regresi logistik multinomial diperoleh hasil tujuh variabel yang dapat memberikan kontribusi secara parsial terhadap model, yaitu variabel motivasi fisik $\left(\mathrm{X}_{4}\right)$, nilai keindahan $\left(\mathrm{X}_{5}\right)$, nilai keaslian/kelestarian $\left(\mathrm{X}_{6}\right)$, sarana yang tersedia $\left(\mathrm{X}_{8}\right)$, aksesibilitas $\left(\mathrm{X}_{9}\right)$, biaya perjalanan $\left(\mathrm{X}_{10}\right)$, dan obyek wisata lain $\left(\mathrm{X}_{11}\right)$. Tujuh variabel tersebut memiliki signifikansi $<0,05$ sehingga menerima hipotesis alternatif. 


\section{Tabel 3 Hasil Analisis Regresi Logistik Multinomial}

\begin{tabular}{|c|c|c|c|c|}
\hline \multirow{2}{*}{ Effect } & $\begin{array}{c}\text { Model } \\
\text { Fitting } \\
\text { Criteria }\end{array}$ & \multicolumn{2}{|c|}{ Likelihood Ratio Tests } \\
\cline { 2 - 5 } & $\begin{array}{c}\text {-2 Log } \\
\text { Likelihood } \\
\text { of Reduced } \\
\text { Model }\end{array}$ & $\begin{array}{c}\text { Chi- } \\
\text { Square }\end{array}$ & df & Sig. \\
& & & \\
\hline Intercept & 275.119 & 24.124 & 8 & .002 \\
X1 & 265.385 & 14.389 & 8 & .072 \\
X2 & 260.739 & 9.744 & 8 & .283 \\
X3 & 254.777 & 3.782 & 8 & .876 \\
X4 & 269.987 & 18.992 & 8 & .015 \\
X5 & 281.179 & 30.184 & 8 & .000 \\
X6 & 273.397 & 22.402 & 8 & .004 \\
X7 & 263.025 & 12.030 & 8 & .150 \\
X8 & 285.884 & 34.888 & 8 & .000 \\
X9 & 275.319 & 24.323 & 8 & .002 \\
X10 & 293.208 & 42.212 & 8 & .000 \\
X11 & 268.968 & 17.972 & 8 & .021 \\
\hline
\end{tabular}

Sumber : Output SPSS 2019, diolah

\section{Keinginan Konservasi dan Tingkat Kunjungan Wisata}

Berdasarkan Tabel 3, variabel keinginan konservasi tidak memiliki pengaruh yang signifikan terhadap tingkat kunjungan wisata pendakian di Jawa Tengah. Hasil tersebut belum memenuhi terminologi ekowisata, yaitu dimana setiap perjalanan wisata bertujuan untuk melakukan konservasi dari aktivitas wisatawan yang dapat merusak kelestarian daya tarik wisata (Damanik dan Weber, 2006). Secara konsep, wisata pendakian dapat diarahkan untuk ekowisata. Namun, pada realitasnya terdapat 46\% wisatawan melakukan kegiatan yang berpotensi merusak lingkungan seperti: tidak membawa sampah turun, membawa peralatan mendaki yang tidak ramah lingkungan, mengambil atau merusak flora dan fauna, dan vandalisme. Meskipun angka tersebut di bawah 50\%, namun untuk kegiatan yang berpotensi merusak lingkungan terutama dilakukan di kawasan pendakian akan sangat sensisitif dan cenderung meningkat. Tujuan wisatawan yang paling dominan adalah bukan untuk berekowisata, melainkan untuk berwisata alam, yaitu menikmati keindahan alam. Meskipun motif berwisata bukan untuk melestarikan lingkungan, namun dalam kegiatan - kegiatan tersebut melekat keinginan untuk ikut serta melestarikan lingkungan (Damanik dan Weber, 2006). Selain itu, upaya konservasi kawasan pendakian dilakukan secara preventif dan persuasif oleh pihak pengelola dalam 
bentuk himbauan maupun kebijakan. Sehingga, keinginan konservasi akan cenderung timbul saat individu sedang melakukan kegiatan pendakian dan bukan menjadi faktor yang dominan dalam memengaruhi keputusan untuk mendaki gunung.

\section{Pengetahuan Konservasi dan Tingkat Kunjungan Wisata}

Tabel 3 menunjukan bahwa pengetahuan konservasi memiliki pengaruh yang tidak signifikan terhadap tingkat kunjungan wisata pendakian di Jawa Tengah. Gambar 3 menunjukan bahwa $46 \%$ wisatawan masih melakukan kegiatan yang berpotensi merusak lingkungan. Kegiatan yang paling banyak dilakukan wisatawan adalah membawa peralatan yang tidak ramah lingkungan saat mendaki gunung. Pemahaman individu tentang koservasi bisa didapatkan melalui keikutsertaannya dalam komunitas pecinta alam/lingkungan hidup. Namun, hanya terdapat $32 \%$ wisatawan yang tergabung dalam komunitas pecinta alam/lingkungan hidup. Penelitian ini tidak mendukung hasil penelitian Sadikin (2017) dan Oktadiyani (2015), dimana kedua obyek wisata dalam penelitian tersebut merupakan kawasan konservasi Taman Nasional sehingga terdapat perbedaan karakteristik responden. Dilihat dari aspek permintaan pariwisata, salah satu faktor yang sangat memengaruhi permintaan pariwisata adalah mobilitas. Mobilitas manusia timbul oleh berbagai macam dorongan kebutuhan atau kepentingan yang disebut dengan istilah motivasi (Spillane, 1987). Sehingga, dalam melakukan kegiatan wisata tidak membutuhkan pengetahuan khusus melainkan adanya dorongan terhadap kebutuhan dan kepentingan.

\section{Kebutuhan Relaksasi dan Tingkat Kunjungan Wisata}

Kebutuhan relaksasi tidak memiliki pengaruh yang signifikan terhadap tingkat kunjungan wisata pendakian di Jawa Tengah. Hasil penelitian ini menunjukan hasil yang berbeda dengan penelitian Li, Bin, and Ryan (2017) yang menyatakan kebutuhan relaksasi berpengaruh signifikan terhadap motivasi individu untuk mendaki gunung. Perbedaan hasil tersebut disebabkan oleh perbedaan obyek wisata dan karakteristik responden penelitian berdasarkan jenis pekerjaan, tujuan wisata, dan lama kunjungan. Berdasarkan jenis pekerjaan, 57\% wisatawan adalah pelajar/mahasiswa yang memiliki lebih banyak waktu luang daripada jam kerja. Sementara itu, wisatawan yang memiliki banyak jam kerja pada umumnya lebih membutuhkan relaksasi ditengah keterbatasan waktu luang. Rata - rata lama kunjungan wisata pendakian di Jawa Tengah yaitu hanya dua hari (74\%). Wisatawan yang benar - benar ingin menjamin kebutuhan relaksasi akan tinggal selama mungkin di tempat - tempat yang dianggapnya bisa memenuhi kenikmatan yang mereka perlukan tersebut (Spillane, 1987). Selain itu, terdapat faktor - faktor lain yang menyebabkan tidak terpenuhinya kebutuhan relaksasi saat mendaki gunung yaitu seperti kondisi cuaca dan tingkat kepadatan pengunjung yang terjadi pada obyek wisata pendakian Gunung Merbabu, Gunung Prau, dan Gunung Andong. Berdasarkan leisure satisfaction scale (Beard dan Ragheb dalam Li, Bin, dan Ryan, 2017) menjelaskan bawah kepuasan individu dapat dicapai melalui motivasi yang terdiri dari komponen psikologis, edukasi, sosial, relaksasi, fisik, dan dimensi 
aestetik. Sehingga, kepuasan dari mendaki gunung dapat dicapai selain dari kebutuhan relaksasi.

\section{Motivasi Fisik dan Tingkat Kunjungan Wisata}

Hasil regresi logit multinomial Tabel 3 menunjukan bahwa motivasi fisik memiliki pengaruh yang signifikan terhadap tingkat kunjungan wisata pendakian di Jawa Tengah. Hasil penelitian ini sesuai dengan penelitian Li, Bin, dan Ryan (2017) dan Beedie dan Hudson (2003). Beedie dan Hudson (2003) dalam penelitiannya yang berjudul Emergence of Mountain Based Adventure Tourism menyatakan bahwa salah satu gagasan yang menyebabkan kemunculan wisata pendakian yaitu terdapat aktivitas fisik luar ruangan yang terlibat secara langsung dan berdampak terhadap penurunan berat badan, perkembangan fisik, dan pengurangan stress. Wisatawan didominasi oleh kalangan usia di bawah 24 tahun (70\%). Faktor usia tersebut menunjukan bahwa, wisatawan dengan usia yang lebih muda cenderung mendapatkan manfaat fisik yang lebih banyak ketika sedang mendaki gunung. Jalur pendakian yang menantang adrenalin menimbulkan motivasi lain untuk mendaki gunung, yaitu preferensi responden terhadap motivasi fisik.

\section{Nilai Keindahan dan Tingkat Kunjungan Wisata}

Hasil penelitian menunjukan bahwa nilai keindahan memiliki pengaruh yang signifikan terhadap tingkat kunjungan wisata pendakian di Jawa Tengah. Nilai keindahan merupakan nilai implisit dari kualitas atribut obyek wisata pendakian. Para wisatawan cenderung mendaki gunung dengan nilai keindahan yang berciri khas. Terdapat $44 \%$ pengunjung mendaki gunung untuk menikmati keindahan alam. Hal tersebut didukung oleh penilaian rata - rata akumulasi preferensi responden sebesar 13,17 yang berada pada kategori skala interval tertarik terhadap nilai keindahan gunung di Jawa Tengah. Berdasarkan data tersebut, maka ketertarikan dengan nilai keindahan dapat memengaruhi keputusan individu untuk mendaki gunung di Jawa Tengah.

\section{Nilai Keaslian/Kelestarian}

Hasil penelitian menunjukan bahwa nilai keaslian/kelestarian memiliki pengaruh yang signifikan terhadap tingkat kunjungan wisata pendakian di Jawa Tengah. Nilai keaslian/kelestarian juga merupakan nilai implisit dimiliki obyek wisata pendakian. Obyek daya tarik wisata pendakian memiliki basis alam dan lingkungan yang asli dan alami, sehingga nilai keaslian berkaitan dengan tingkat kelestarian suatu obyek. Hal tersebut sesuai dengan teori menurut Beedie dan Hudson (2003) yang menyatakan bahwa faktor - faktor yang memengaruhi wisata petualangan kemudian akan memunculkan pariwisata berbasis pendakian gunung. Faktor - faktor tersebut meliputi: karakteristik alam liar, kegiatan petualangan, nilai keaslian, dan nilai kebebasan. Damanik dan Weber (2006) juga menyatakan bahwa, atraksi alam yang masih asli memiliki nilai tertinggi dalam kepuasan berwisata. 


\section{Atraksi Obyek Wisata}

Atraksi obyek wisata memiliki pengaruh yang tidak signifikan terhadap tingkat kunjungan wisata pendakian di Jawa Tengah. Hasil penelitian ini berbeda dengan hasil penelitian terdahulu yang dilakukan oleh Abdurahman (2016). Meskipun atraksi sudah tersedia, perlu diperhatikan atribut lain yang menarik wisatawan pertamakali. Atribut tersebut merupakan atribut yang sesuai dengan karakteristik obyek wisata. Salah satu atribut utama yang perlu diperhatikan untuk mencapai atraksi pada wisata pendakian adalah aksesibilitas menuju atraksi, yaitu jalur pendakian. Perbedaan karakteristik gunung di Jawa Tengah menyebabkan atraksi yang dimiliki gunung - gunung di Jawa Tengah berada pada lokasi yang sulit dilalui. Selain itu, atribut dalam wisata berbasis alam bebas didasari oleh kebutuhan psikologis untuk berada pada lingkungan yang alami (Abdurahman et al., 2016). Sehingga, kemampuan obyek untuk menarik wisatawan tergantung pada kualitas lingkungannya (Ceballos dalam Abdurahman, 2016). Karakteristik gunung yang berbeda menyebabkan perbedaan tingkat kesulitan dan jarak untuk mencapai atraksinya. Para pendaki cenderung hanya untuk menikmati suasana dan lingkungan yang asri dan alami serta beranggapan bahwa atraksi adalah bonus dari sebuah perjalanan. Unsur lain yang dapat menarik wisatawan selain daya tarik yang dimilikinya, antara lain sarana dan prasarana, infrastruktur, dan masyarakat/lingkungan (Suwantoro 1997, h.19)

\section{Sarana yang Tersedia dan Tingkat Kunjungan Wisata}

Berdasarkan hasil ouput regresi logit multinomial, sarana yang tersedia berpengaruh signifikan terhadap tingkat kunjungan wisata pendakian di Jawa Tengah. Hasil akumulasi nilai rata - rata preferensi responden terhadap sarana yang tersedia adalah sebesar 12,35 yang menunjukan kategori penilaian cukup baik terhadap kualitas dan kuantitas sarana yang tersedia. Selain atraksi yang dimiliki suatu obyek, atribut pendukung seperti sarana dan aksesibilitas juga menjadi faktor yang penting untuk menarik minat wisatawan (Abdurahman et al., 2016,). Pengadaan sarana wisata tersebut harus disesuaikan dengan kebutuhan wisatawan baik secara kuantitatif maupun kualitatif (Suwantoro, 1997).

\section{Aksesibilitas Obyek Wisata}

Hasil penelitian menunjukan bahwa aksesibilitas obyek wisata berpengaruh signifikan terhadap tingkat kunjungan wisata pendakian di Jawa Tengah. Aksesibilitas obyek wisata merupakan tingkat kemudahan untuk menuju kawasan pendakian yang meliputi tingkat kemudahan jalan menuju kawasan pendakian, kemudahan dan keamanan jalur pendakian, dan ketersediaan sarana transportasi menuju kawasan pendakian di Jawa Tengah. Aksesibilitas merupakan fungsi harga hedonis yang digunakan untuk menggambarkan nilai implisit atribut wisata dan merupakan pengembangan variabel pada penelitian terdahulu yang telah disesuaikan. Nilai rata - rata akumulasi preferensi responden terhadap aksesibilitas obyek wisata pendakian di Jawa Tengah adalah 12,13. Nilai tersebut berada pada interval kelas 12,1 - 13,0 yang berarti bahwa wisatawan menilai cukup baik terhadap aksesibilitas obyek wisata pendakian di Jawa Tengah. 


\section{Biaya Perjalanan}

Biaya perjalanan merupakan faktor yang dapat memengaruhi keputusan untuk mendaki gunung. Preferensi dan anggaran pengeluaran adalah faktor penentu utama permintaan pariwisata (Sinclair dan Stabler, 1997). Dalam metode Hedonic Travel Cost, harga implisit dari atribut wisata diperoleh dari hasil regresi biaya perjalanan yang dikeluarkan terkait atribut yang disediakan obyek wisata (Yen dan Sohngen, 2014). Hal ini menunjukan bahwa, perilaku pegunjung dalam memaksimalkan utilitasnya adalah sama dengan jumlah anggaran yang dibelanjakan. Utilitas marjinal atribut wisata sama dengan biaya marjinalnya yang bersedia dibayarkan (marginal willingness to pay) dari tiap atribut yang dirasakan. Sehingga, biaya relatif yang dikeluarkan wisatawan merupakan harga implisit untuk memperoleh nilai kesenangan dari mendaki gunung. Keputusan berkunjung ke wisata pendakian di Jawa Tengah merupakan salah satu contoh hasil dari perilaku irasional, dimana besaran biaya perjalanan yang dikeluarkan dapat meningkatkan tingkat kunjungan wisata pendakian. Tingginya minat wisata pendakian di Jawa Tengah merupakan dampak dari efek ikut - ikutan (bandwagon effect) dan efek pamer (Veblen effect). Dengan adanya kedua efek tersebut, maka obyek wisata pendakian dapat diklasifikasikan sebagai barang superior. Biaya yang dibayarkan merupakan biaya ikut - ikutan, biaya pamer, dan biaya implisit atas nilai kesenangan yang bersedia dikeluarkan wisatawan.

\section{Obyek Wisata Lain}

Obyek wisata lain, yaitu biaya perjalanan kunjungan ke Dataran Tinggi Dieng memengaruhi keputusan wisatawan mendaki gunung di Jawa Tengah. hasil penelitian ini sesuai dengan teori yang dinyatakan Sinclair dan Stabler (1997), yaitu seseorang dapat mengambil sebuah keputusan tidak hanya untuk mengombinasikan antara kebutuhan pariwisata dengan kebutuhan konsumsi lain, namun juga dapat mengombinasikan keputusannya diantara dua tipe kebutuhan pariwisata yang berbeda. Pada kasus tipe pariwisata yang berbeda, individu memilih kombinasi dari tipe pariwisata yang dapat bersifat substitusi atau komplementer. Hubungan obyek wisata pendakian di Jawa Tengah dengan obyek wisata Dataran Tinggi Dieng adalah saling menggantikan atau substitusi. Wisatawan cenderung tidak bersedia untuk mendaki gunung dan mengunjungi Dataran Tinggi Tinggi dalam satu rangkaian perjalanan.

\section{KESIMPULAN}

\section{Kesimpulan}

Faktor - faktor yang dapat memengaruhi tingkat kunjungan wisata pendakian di Jawa Tengah adalah motivasi fisik, nilai keindahan, nilai keaslian/kelestarian, sarana yang tersedia, aksesibilitas obyek wisata, biaya perjalanan menuju obyek wisata pendakian, dan biaya perjalanan menuju obyek wisata Dataran Tinggi Dieng. Dalam melakukan wisata pendakian, wisatawan tidak harus memiliki pengetahuan khusus, melainkan adanya dorongan terhadap kebutuhan dan kepentingan wisatawan yang memengaruhi keputusannya untuk mendaki gunung. 
Faktor - faktor lain yang dapat memengaruhi kebutuhan relaksasi perlu dipertimbangkan seperti cuaca ekstrim dan kepadatan pengunjung obyek wisata pendakian. Jalur pendakian yang menantang adrenalin akan mendorong wisatawan untuk melakukan gerak fisik dan memberikan manfaat fisik. Hal tersebut dapat mendorong motivasi fisik yang dapat memengaruhi keputusan mendaki gunung. Selain kepuasan pengunjung atas manfaat yang dirasakan, nilai implisit dari atribut wisata pendakian dapat memengaruhi keputusan seseorang untuk mendaki gunung. Nilai implisit dari atribut tersebut yaitu: nilai keindahan, nilai keaslian/kelestarian, sarana yang tersedia, dan aksesibilitas obyek wisata.

Perilaku wisatawan dalam memutuskan untuk mendaki gunung dapat dilihat dari besaran biaya perjalanannya. Biaya perjalanan merupakan faktor yang dapat memengaruhi keputusan untuk mendaki gunung. Biaya yang dibayarkan merupakan biaya ikut - ikutan, biaya pamer, dan biaya implisit atas nilai kesenangan yang bersedia dikeluarkan wisatawan. Selain itu, keputusan untuk mendaki gunung di Jawa Tengah dipenagaruhi biaya perjalanan menuju obyek Dataran Tinggi Dieng. Hubungan kedua obyek wisata tersebut adalah saling menggantikan atau substitusi.

\section{Saran}

Nilai implisit dan atraksi obyek wisata pendakian akan sangat bergantung pada tingkat kelestariannya. Diharapkan pihak pengelola dan pengunjung obyek wisata bekerja sama untuk menjaga kelestarian kawasan pendakian. Kepadatan pengunjung wisata pendakian dapat mengurangi manfaat relaksasi yang menjadi tujuan pengunjung. Sehingga perlu diterapkan kebijakan pembatasan pengunjung untuk menjamin terpenuhinya kebutuhan relaksasi serta dapat menjaga kelestarian daya tarik wisata pendakian. Selain usaha preventif tersebut, pihak pengelola dan instansi terkait wajib memberikan edukasi untuk mengurangi dampak negatif yang timbul dari kegiatan pendakian yang semakin berkembang

Nilai atribut pendukung wisata, seperti sarana dan aksesibilitas perlu diperhatikan. Diharapkan pihak pengelola terus menambah kualitas dan kuantitas sarana, terutama sarana prasarana keamanan wisata pendakian. Selain itu, kemudahan transportasi umum dapat ditingkatkan melalui kerjasama warga sekitar dengan stasiun dan terminal terdekat dalam penyediaan transportasi umum. Penelitian selanjutnya diharapkan mampu mengembangkan penelitian ini dengan melakukan estimasi nilai kerugian ekonomi dan ketersediaan membayar wisatawan akibat dampak negatif yang ditimbulkan dari aktivitas mendaki gunung.

\section{DAFTAR PUSTAKA}

Abdurahman, A. Z. A., Ali, J. K., Khedif, L. Y. B., Bohari, Z., Ahmad, J. A., dan Kibat, S. A. 2016. Ecotourism Product Attributes and Tourist Attractions: UiTM Undergraduate Studies. Journal of Social and Behavioral Sciences, hal. 360-367.

Beedie, P., dan Hudson, S. 2003. Emergence of Mountain-Based Adventure Tourism. Annals of Tourism Research, hal. 625-643. 
Canteiro, M., Córdova-Tapia, F., dan Brazeiro, A. 2018. Tourism Impact Assessment: A Tool to Evaluate the Environmental Impacts of Touristic Activities in Natural Protected Areas. Journal of Tourism Management Perspectives, hal. 220-227.

Case dan Fair. 2007. Prinsip-Prinsip Ekonomi. Jakarta : Erlangga.

Damanik dan Weber. 2006. Perencanaan Ekowisata : Dari Teori ke Aplikasi. Jogjakarta : Puspar UGM Penerbit Andi Yogyakarta.

Fandeli, Nurdin. 2005. Pengembangan Ekowisata Berbasis Konservasi di Taman Nasional. Jogjakarta : Fakultas Kehutanan Universitas Gajah Mada.

Fauzi, Akhmad. 2004. Ekonomi Sumber Daya Alam dan Lingkungan. Jakarta : Gramedia Pustaka Utama.

Ghozali, Imam. 2006. Analisis Multivariate Lanjutan. Semarang : Badan Penerbit Universitas Diponegoro.

Herpen, E. Van, Pieters, R., dan Zeelenberg, M. 2009. When Demand Accelerates Demand : Trailing the Bandwagon. Journal of Consumer Psychology, hal. 302312 .

Li, P., Bin, Z., dan Ryan, C. 2017. Hiking in China: A Fuzzy Model of Satisfaction. Journal of Tourism Management Perspectives, hal. 90-97.

Nugraha, A. E., dan Purwanti, E. Y. 2015. Analisis Faktor - Faktor yang Mempengaruhi Permintaan Pengunjung Obyek Wisata Menara Kudus Melalui Pendekatan Hedonic Pricing Method. Journal of Economics, hal. 1-9.

Oktadiyani, P. 2015. Taman Wisata Alam Wera Ecotourism Development Strategy of Wera. Jurnal Wasian, hal. 9-20.

Pindyck dan Rubinfeld. 2005. Mikroekonomi. New Jersey : Pearson.

Sadikin, P. N., Mulatsih, S., Pramudya, B., dan Arifin, H. S. 2017. Analisis Willingness-To-Pay Pada Ekowisata Taman Nasional Gunung Rinjani. Jurnal Analisis Kebijakan Kehutanan, hal. 31-46.

Santarém, F., Silva, R., dan Santos, P. 2015. Assessing Ecotourism Potential of Hiking Trails: A Framework to Incorporate Ecological and Cultural Features and Seasonality. Journal of Tourism Management Perspectives, hal. 190-206.

Sinclair dan Stabler. 1997. The Economics of Tourism. New York : Routledge.

Spillane.1987. Ekonomi Pariwisata: Sejarah dan Prospeknya. Yogyakarta : Kanisius. 
Sudarsono.1983. Pengantar Ekonomi Mikro. Jakarta : Lembaga Penelitian, Pendidikan, dan Penenrangan Ekonomi dan Sosial.

Sugiyono. 2013. Metode Penelitian Kuantitatif, Kualitatif, dan R\&D. Bandung : Alfabeta.

Sukanto dan Andreas. 2000. Ekonomi Lingkungan : Suatu Pengantar. Yogyakarta : BPFE Yogyakarta.

Suwantoro. 1997. Dasar-Dasar Pariwisata. Yogyakarta : Penerbit Andi.

Yeh, C., dan Sohngen, B. L. 2004. Estimating Dynamic Recreational Demand by the Hedonic Travel Cost Method. American Agricultural Economics Association Annual Meetings Denver, Agricultural and Applied Economics Association, hal. 1-4. 